\title{
Relationship among Different Soil Biochemical Methods to Determine Soil Health
}

\author{
Amitava Chatterjee, Umesh Acharya \\ Department of Soil Science, North Dakota State University, Fargo, USA \\ Email: amitava.chatterjee@ndsu.edu
}

How to cite this paper: Chatterjee, A. and Acharya, U. (2018) Relationship among Different Soil Biochemical Methods to Determine Soil Health. Open Journal of Soil Science, 8, 303-313. https://doi.org/10.4236/ojss.2018.811022

Received: October 8, 2018

Accepted: November 12, 2018

Published: November 15, 2018

Copyright $\odot 2018$ by authors and Scientific Research Publishing Inc. This work is licensed under the Creative Commons Attribution International License (CC BY 4.0).

http://creativecommons.org/licenses/by/4.0/

(c) (i) Open Access

\begin{abstract}
Numerous soil biochemical methods are used to determine the soil health status, but the relationships among these methods are not well understood. Relationships among soil biochemical tests, 1) chloroform fumigated microbial biomass C (CFMBC), 2) permanganate oxidizable C (POXC), 3) Solvita $\mathrm{CO}_{2}$-burst (Solvita), 4) Solvita labile amino nitrogen (SLAN), and short-term soil $\mathrm{CO}_{2}$ efflux during laboratory incubation using (v) Alkali-base trap (Alkali) and (vi) infrared gas analyzer (IRGA), were evaluated for nine agricultural soils collected across the Red River Valley of North Dakota and Minnesota, USA. Not a single test is comprehensive to relate with all soil biochemical tests. Coefficient of variation percentage for particular method varied with soil type. Among six tests, CFMBC is significantly $(\mathrm{p}<0.05)$ related with Alkali $(r=0.37)$, Solvita $(r=0.57)$, SLAN $(r=0.52)$, and POXC $(r=0.68)$. Soil CFMBC correlates with most of soil biochemical tests and can be potential to determine soil biochemical condition.
\end{abstract}

\section{Keywords}

Chloroform Fumigated Microbial Biomass Carbon, Solvita $\mathrm{CO}_{2}$-Burst, Soil Labile Amino Nitrogen (SLAN), Permanganate Oxidizable Carbon, Infrared Gas Analyzer, Soil Organic Carbon

\section{Introduction}

Measuring soil health has been gaining popularity due to the growing consensus about protecting the agricultural sustainability [1] [2]. Different commercial test kits like Solvita $\mathrm{CO}_{2}$-burst ${ }^{\circledR}$ ) [3] and standard laboratory methods like permanganate-oxidizable carbon (POXC) [4] and mineralizable C (as determined by short-term aerobic incubation of rewetted soil), are available to assess the soil health condition rapidly. The concept of the labile $\mathrm{C}$ pool, behind these me- 
thods, is the most biologically active and sensitive to shift in management practices [5]. However, these tests have the potential to predict nutrient availability and supply to crops [6]. The main goal of this study is to determine the associations between rapid soil biochemical tests and soil properties. Understanding their relationships will help them to utilize their potential to the fullest.

The relationships among soil biochemical health tests are not straight-forward [7]. Moreover, their relationship and sensitivity are strongly influenced by landscape characteristics [8], inherent soil properties like texture [9] and crop and soil management practices like tillage and rotation [10] [11] [12]. Some soil biological tests are more sensitive to shift with soil factors than other tests.

For this study, soil samples were collected from nine different agricultural fields of the Red River Valley of North Dakota and Minnesota, USA, to study the relationships among soil properties and selected rapid soil biochemical tests. It was hypothesized that soil health function is significantly correlated with soil properties across soil and crop management practices. Six soil biochemical properties, 1) soil organic matter (SOM), 2) soil $\mathrm{pH}, 3)$ soil electrical conductivity, 4) soil nitrate-nitrogen $\left.\left(\mathrm{NO}_{3}-\mathrm{N}\right), 5\right)$ Olsen-extracted phosphorus (P), and 6) soil organic carbon (SOC) were selected. Six soil biochemical health tests were determined: a) chloroform fumigated microbial biomass C (CFMBC), b) POXC, c) Solvita labile amino nitrogen (SLAN), and mineralizable C pool using d) $\mathrm{NaOH}$-base trap (Alkali), e) infrared gas analyzer (IRGA), and f) Solvita $\mathrm{CO}_{2}$-burst tests. Main objectives were to understand the i) variability of response in soil properties and soil biochemical health tests and ii) relationships among rapid soil biochemical tests and soil properties for agricultural soils in the Northern Great Plains.

\section{Materials and Methods}

\subsection{Soil Sampling}

During fall 2016, soil samples of $0-15 \mathrm{~cm}$ depth were collected using a bucket-auger from nine different agricultural fields across the Red River Valley of North Dakota and Minnesota, United States of America. All sites are located under temperate climate. Details about sampling sites are presented in Table 1. Soil classification information was collected from the Web Soil Survey (https://websoilsurvey.sc.egov.usda.gov/App/HomePage.htm). Soil samples were air-dried, passed through $2 \mathrm{~mm}$ sieve.

\subsection{Soil Analysis}

Samples from each site were divided into five subsamples for the laboratory analysis. Basic soil properties were analyzed as outlined in "Recommended Chemical Soil Test Procedures for the North Central Region" [13]. Soil water holding capacity (WHC) was determined using the Pressure-plate method [14]. Soil $\mathrm{pH}$ and electrical conductivity (EC) were measured using $\mathrm{pH} / \mathrm{CON} 450$ meter (Oakton Instruments, Vernon Hills, IL, USA) with soil water ratio of 1:2.5 
[15]. Soil $\mathrm{NO}_{3}^{-}$concentration was determined by extracting $5 \mathrm{~g}$ soil samples with $25 \mathrm{ml}$ of $2 \mathrm{M} \mathrm{KCl}$ and subsequently analyzed the aliquot with TL-2800 ammonia analyzer (Timberline Instruments, Boulder, $\mathrm{CO}$, USA) using $\mathrm{KCl}$ extraction [16]. The concentration of soil available phosphorus (P) or Olsen-P, was measured spectrophotometrically after extraction of soils with sodium bicarbonate [17]. Soil Organic Carbon (SOC) was determined by the dry combustion method [18] at $1000^{\circ} \mathrm{C}$ using CA-100 Primacs ${ }^{\text {SC }}$ TOC analyzer (Skalar Analytic, Norcross, GA). The CFMBC of soil samples were analyzed using chloroform fumigation method [19]. Briefly, a duplicate set of $20 \mathrm{~g}$ of each air-dry subsamples was incubated for 7 days at $50 \%$ of WHC. After 7 days, the first set of soil was fumigated with ethanol-free chloroform in the dark for 72 hours, while other set were treated as control. Both sets of soil were extracted with $50 \mathrm{ml}$ of $0.5 \mathrm{M}$ $\mathrm{K}_{2} \mathrm{SO}_{4}$ after shaken in a reciprocal shaker (200 strokes per minute) for an hour and filtered through Whatman No. 2 filter paper. Extracts were analyzed for dissolved organic carbon (DOC) using the Shimadzu TOC-VCPH/CPN Analyzer (Shimadzu Corp., Kyoto, Japan). The CFMBC $\left(\mathrm{mg} \mathrm{C} \mathrm{kg}^{-1}\right)$ was calculated by dividing the difference in DOC values of the fumigatwed and non-fumigated soil samples with a correction factor (Kc) of 0.45 [19].

Five rapid soil biochemical tests, 1) POXC, 2) Solvita labile amino nitrogen (SLAN) kit and soil $\mathrm{CO}_{2}$ efflux from laboratory using 3) alkali base trap (Alkali), 4) infrared gas analyzer (IRGA), and 5) Solvita $\mathrm{CO}_{2}$-burst kit (Solvita), were analyzed for 45 soil samples ( 9 samples $\times 5$ pseudo replicates). The POXC was analyzed as described by [20]. Briefly, $5 \mathrm{~g}$ of air-dried soil was weighed into 50 $\mathrm{ml}$ polypropylene conical centrifuge tube to which $18 \mathrm{ml}$ of deionized water and $2 \mathrm{ml}$ of $2 \mathrm{M} \mathrm{KMnO}_{4}$ were added and vigorously shaken for 2 minutes on a reciprocal shaker (240 oscillations per minute) under room temperature. After 2 minutes, tubes were swirled vigorously by hand to ensure no soil clinging to sides or cap of the tube. Tubes were placed in the dark area to allow the soil to settle precisely for 10 minutes. After 10 minutes, $0.5 \mathrm{ml}$ of supernatant from the upper $1 \mathrm{~cm}$ of the suspension transferred fast to a second tube containing $49.5 \mathrm{ml}$ of deionized water and was inverted to mix. The diluted solution was measured for its absorbance in a spectrophotometer, V-1200 (VWR International Ltd., Randor, Pennsylvania, USA) set at $550 \mathrm{~nm}$ wavelength. The values for $\mathrm{KMnO}_{4}-\mathrm{C}$ were determined using the following equation [20]:

$$
\begin{aligned}
\operatorname{POXC}\left(\mathrm{mg} \mathrm{kg}^{-1}\right)= & {\left[0.02 \mathrm{~mol} \mathrm{~L}^{-1}-(\mathrm{a}+\mathrm{b} \times \text { absorbance })\right] } \\
& \times\left(9000 \mathrm{mg} \mathrm{C} \mathrm{mol}^{-1}\right) \times\left(\frac{0.02 \mathrm{~L} \text { solution }}{0.005 \mathrm{~kg} \text { soil }}\right)
\end{aligned}
$$

where, $0.02 \mathrm{~mol} \mathrm{~L}^{-1}$ is the initial solution concentration, $\mathrm{a}$ is the intercept and $\mathrm{b}$ is the slope of the standard curve, 9000 is $\mathrm{mg} \mathrm{C}$ oxidized by $1 \mathrm{~mol}$ of $\mathrm{MnO}_{4}$ changing from $\mathrm{Mn}^{7+}$ to $\mathrm{Mn}^{4+}, 0.02 \mathrm{~L}$ is the volume of $\mathrm{KMnO}_{4}$ solution reacted, and 0.005 is the $\mathrm{kg}$ of soil used.

Short-term laboratory incubation method was used to determine soil $\mathrm{CO}_{2}$ evolution, to estimate the mineralizable carbon. Soil $\mathrm{CO}_{2}$ flux from lab incuba- 
tion was measured using 1) alkali trap (Alkali), 2) infrared gas analyzer (IRGA) and 3) Solvita gel system (Woods End Laboratories Inc. Mt. Vernon, ME). For all three methods, $50 \mathrm{~g}$ of air-dried soils were weighed into a $0.5 \mathrm{~L}$ mason jar, and deionized water was added to bring soil to $50 \%$ WHC. For alkali trap method, $20 \mathrm{ml}$ of $0.5 \mathrm{M} \mathrm{NaOH}$ in the vial was inserted in the jar and incubated for four days at $25^{\circ} \mathrm{C}$. The vial containing $\mathrm{NaOH}$ was titrated with $0.5 \mathrm{M} \mathrm{HCl}$ to determine $\mathrm{CO}_{2}$ evolved during incubation [21]. A separate set of incubated soils was used to determine soil $\mathrm{CO}_{2}$ efflux using IRGA, Li-800 (LI-COR Bioscience, Lincoln, Nebraska, USA), after five days of incubation. Headspace air samples were collected inserting $5 \mathrm{ml}$ syringe through rubber septum fitted on the jar lid. Headspace $\mathrm{CO}_{2}$ concentration ( $\mathrm{mg} \mathrm{kg}^{-1}$ ) was converted to $\mathrm{CO}_{2}-\mathrm{C} \mu \mathrm{g} \mathrm{g}^{-1}$ day $^{-1}$ using ideal gas equation. For Solvita gel system, (Woods End Laboratories, Mt. Vernon, ME), $40 \mathrm{~g}$ of air-dried soils were weighed in $50 \mathrm{ml}$ plastic graduated beaker provided in the kit. Deionized water was dispensed using a hand sprayer to avoid forming of the crater in the soil to bring soil in $50 \%$ water holding capacity. Solvita- $\mathrm{CO}_{2}$ probe was inserted into the glass jar alongside the beaker with the gel facing out for observation and lid was tightly screwed. Jars were kept at a stable temperature of $25^{\circ} \mathrm{C}$. After 24 hours, the detector probe was removed, and reading was observed in $\mathrm{CO}_{2} \mathrm{mg} \mathrm{kg}^{-1}$ using Sovita Digital Color Reader (DCR). Similarly, $\mathrm{NH}_{3}$ probe was used to determine SLAN ( $\mathrm{mg} \mathrm{NH}_{4}-\mathrm{N} \mathrm{kg}^{-1}$ ) after adding $2 \mathrm{~N} \mathrm{NaOH}$.

\subsection{Statistical Analysis}

For statistical analysis, five-pseudo replicates (subsamples) were used to calculate the standard deviation and mean. Relationships among soil parameters were statistically analyzed using Pearson correlation coefficient and regression equation fit using SAS Enterprise Guide 7.1 (SAS Institute, Cary, NC) at $\mathrm{p}<0.05$.

\section{Results and Discussion}

\subsection{Soil Properties}

Collected nine soil samples represent a significant range of agricultural soils comprising seven different soil series with the textural class ranging from fine to coarse-silty, covering mainly corn-soybean or wheat based rotation (Table 1). Soil WHC ranged between 0.19 to $0.38 \mathrm{~g} \mathrm{~g}^{-1}$; soil $\mathrm{pH}$ was neutral to moderately alkaline with EC ranged between non-saline $\left(<1 \mathrm{dS} \mathrm{m}^{-1}\right)$ soils at Inkster to very high saline soils at Embden $\left(8.69 \mathrm{dSm}^{-1}\right)$. Soil $\mathrm{NO}_{3}-\mathrm{N}$ concentration ranged between low $\left(<6 \mathrm{mg} \mathrm{kg}^{-1}\right)$ to very high $\left(>30 \mathrm{mg} \mathrm{kg}^{-1}\right)$ availability, but Olsen-P was mostly high $\left(16-20 \mathrm{mg} \mathrm{kg}^{-1}\right)$ to very high $\left(>20 \mathrm{mg} \mathrm{kg}^{-1}\right)$. Soil OM content ranged from 22.8 to $45.7 \mathrm{~g} \mathrm{~kg}^{-1}$. Soil $\mathrm{OC}$ ranged from $15.1 \mathrm{~g} \mathrm{~kg}^{-1}$, at Gardner to $39.8 \mathrm{~g} \mathrm{~kg}^{-1}$, at Dilworth. Ranges of $\mathrm{CV} \%$ for $\mathrm{pH}, \mathrm{EC}, \mathrm{NO}_{3}-\mathrm{N}$, Olsen-P and SOM are $0.25-1.42,1.32-10.2,1.68-15.5,4.48-17.4$, and $1.89-7.61$, respectively.

These values are a close match with the average ND soils as reported in previous literature [22] reported a soil $\mathrm{pH}$ range from 5.3 to a high of 8.5 for $0-15 \mathrm{~cm}$ 


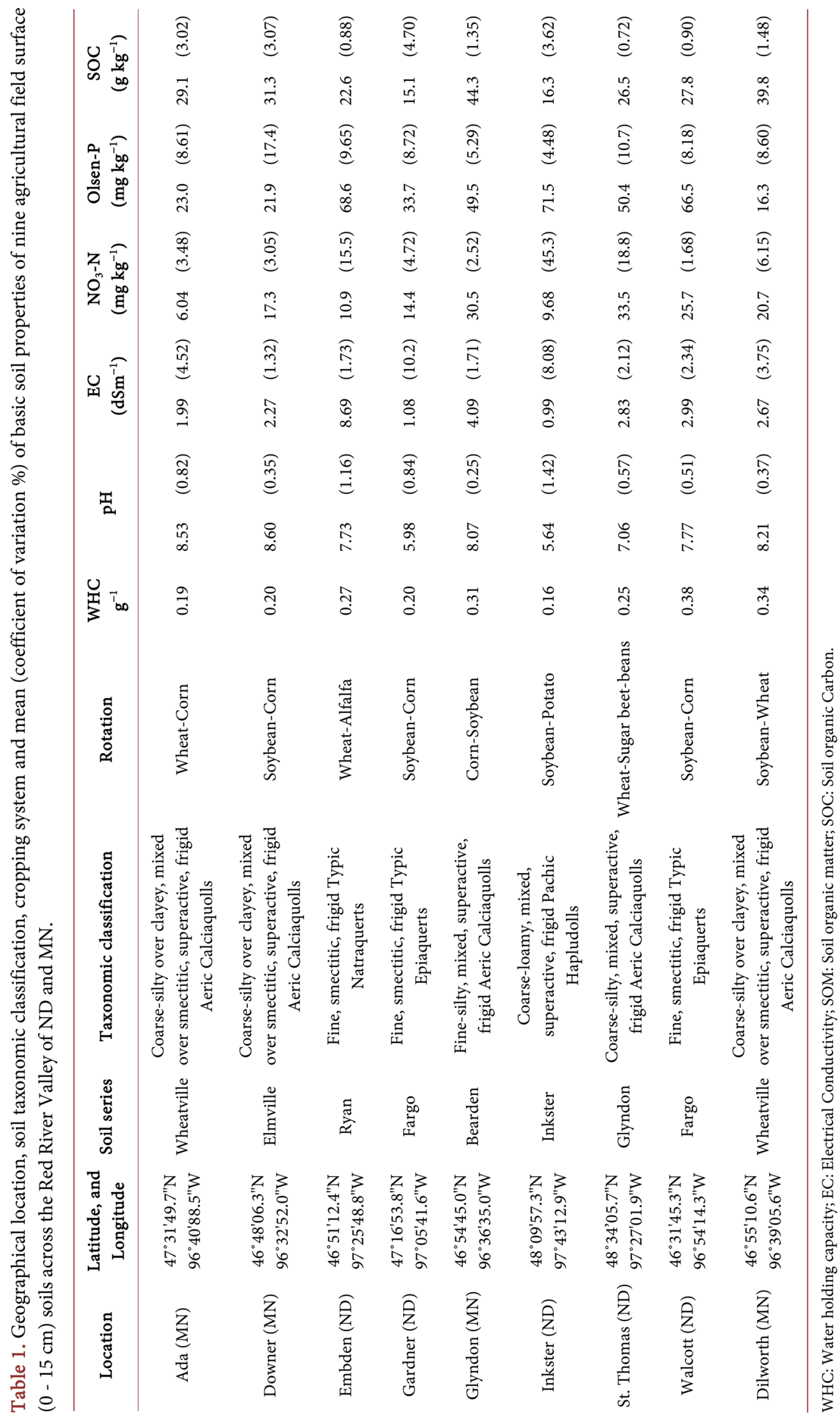


depth soil samples collected from 53 counties in North Dakota. Critical Bray and Kurtz-P level of ND soil is $20 \mathrm{ppm}$ [23]. [12] also reported similar SOM and SOC values of $6.84 \%-9.07 \%$ and $30.0-37.3 \mathrm{~g} \mathrm{~kg}^{-1}$, respectively for agricultural soils under different crop rotations.

\subsection{Soil Biochemical Tests}

Soil biochemical test results of nine agricultural soils were reported in Table 2 . Values for Soil CFMBC, POXC, SLAN, IRGA, Alkali and Solvita range between 867.6 - $2609 \mathrm{mg} \mathrm{C} \mathrm{kg}{ }^{-1}, 226-785 \mathrm{mg} \mathrm{C} \mathrm{kg}{ }^{-1}, 52-164 \mathrm{mg} \mathrm{NH}{ }_{3}-\mathrm{N} \mathrm{kg}^{-1}$, 18.4 - $180 \mathrm{mg} \mathrm{CO}_{2}-\mathrm{C} \mathrm{kg}^{-1} \mathrm{day}^{-1}, 40.5-108 \mathrm{mg} \mathrm{CO}_{2}-\mathrm{C} \mathrm{kg}^{-1} \mathrm{day}^{-1}$, and 61.8 - 135 $\mathrm{mg} \mathrm{CO}{ }_{2}-\mathrm{C} \mathrm{kg}^{-1} \mathrm{day}^{-1}$, respectively. Highest and lowest values of CFMBC, POXC, SLAN, IRGA, Alkali and Solvita are observed at Inkster and Walcott, Inkster and Glyndon, Inkster and Glyndon, St. Thomas and Downer, Inkster and Ada, St. Thomas and Downer, respectively. Lowest and highest values of coefficient of variation percentage $(\mathrm{CV})$ are 6.72 - 13.5, 4.27 - 36.6, 7.29 - 22.4, 2.52 - 26.4, 2.67 - 19.1, and 5.48 - 17.4 for CFMBC, POXC, SLAN, IRGA, Alkali, and Solvita, respectively.

It is interesting to notice that the lowest values are consistently observed at either Inkster or St. Thomas; whereas the highest values are found within Walcott, Glyndon, Downer, and Ada. Values of CV indicate that reproducibility varies with site and test method. Reproducibility of determination methods, as indicated by the average $\mathrm{CV}$ of soil biochemical tests, follows the order of Alkali $(8.16)<$ POXC (9.04) < CFMBC (9.26) < Solvita (10.28) < IRGA (11.6) < SLAN (12.8).

\subsection{Relationship between Soil Biochemical Health Tests and Soil Properties}

Pearson correlation coefficient and significance among soil biochemical tests

Table 2. Mean (CV\%) values of soil biological health parameters of different soil samples collected from agricultural field across the RRV of ND and MN.

\begin{tabular}{|c|c|c|c|c|c|c|c|c|c|c|c|c|}
\hline \multirow{3}{*}{$\begin{array}{l}\text { Location } \\
\text { Ada }\end{array}$} & \multirow{2}{*}{\multicolumn{2}{|c|}{$\begin{array}{c}\text { CFMBC } \\
\mathrm{mg} \mathrm{C} \mathrm{kg}^{-1}\end{array}$}} & \multirow{2}{*}{\multicolumn{2}{|c|}{$\begin{array}{c}\text { POXC } \\
\mathrm{mg} \mathrm{C} \mathrm{kg}^{-1}\end{array}$}} & \multirow{2}{*}{\multicolumn{2}{|c|}{$\begin{array}{c}\text { SLAN } \\
\mathrm{mg} \mathrm{NH}_{3}-\mathrm{N} \mathrm{kg}^{-1}\end{array}$}} & \multicolumn{2}{|c|}{ IRGA } & \multicolumn{2}{|c|}{ Alkali } & \multicolumn{2}{|c|}{ Solvita } \\
\hline & & & & & & & & & $\mathrm{CO}_{2}$ & $\mathrm{~kg}^{-1}$ day & & \\
\hline & 1015 & (13.5) & 488 & $(4.27)$ & 98.6 & $(7.29)$ & 45.4 & $(18.3)$ & 108 & $(5.80)$ & 70.0 & (12.3) \\
\hline Downer & 1557 & $(10.3)$ & 503 & $(5.40)$ & 97.0 & (14.5) & 180 & $(26.4)$ & 83.3 & $(2.67)$ & 135 & (5.48) \\
\hline Embdon & 1496 & (6.73) & 761 & $(5.48)$ & 109 & (16.2) & 28.9 & (9.48) & 44.6 & (19.1) & 78.2 & (11.0) \\
\hline Gardner & 1239 & $(12.2)$ & 553 & $(6.27)$ & 101 & $(16.2)$ & 97.8 & (23.5) & 63.8 & $(4.12)$ & 107 & $(7.23)$ \\
\hline Glyndon & 1873 & $(7.91)$ & 785 & $(4.98)$ & 164 & $(8.32)$ & 77.6 & (11.9) & 91.1 & (10.6) & 92.6 & (17.4) \\
\hline Inkster & 867.6 & $(7.56)$ & 226 & $(36.6)$ & 52.0 & $(22.4)$ & 32.6 & $(2.52)$ & 40.5 & $(3.23)$ & 63.5 & (12.5) \\
\hline St. Thomas & 1272 & $(6.72)$ & 672 & $(8.11)$ & 144 & $(10.4)$ & 18.4 & $(3.32)$ & 64.7 & $(13.4)$ & 61.8 & (15.4) \\
\hline Walcott & 2609 & (7.99) & 719 & $(5.77)$ & 140 & (9.76) & 75.3 & $(5.43)$ & 84.9 & $(8.78)$ & 117 & (4.05) \\
\hline Dilworth & 1749 & $(10.5)$ & 609 & $(4.50)$ & 147 & (11.4) & 47.7 & $(3.96)$ & 99.3 & $(5.86)$ & 85.1 & (7.13) \\
\hline
\end{tabular}

IRGA: Infrared Gas analysis soil respiration; SLAN: Solvita Labile Amino-Nitrogen; POXC: Permanganate-oxidizable Carbon; SOC: Soil organic Carbon; CFMBC: Chloroform fumigation extraction-microbial biomass carbon; Alkali: Base-trap method; Solvita: $\mathrm{CO}_{2}$ burst test. 
and properties are presented in Table 3. Soil CFMBC had a significant relationship with soil properties like SOC, $\mathrm{pH}, \mathrm{NO}_{3}-\mathrm{N}$, and $\mathrm{SOM}$ and with soil biochemical tests, Alkali, Solvita, SLAN, and POXC. Regression equation fit of SLAN and POXC with CFMBC showed a significant quadratic fit (Figure 1(a) and Figure 1(b)). Soil mineralizable $C$ measured by IRGA had a significant negative relationship with Olsen-P and Solvita; and IRGA also had a significant quadratic relationship with Solvita (Figure $1(\mathrm{c})$ ). Similarly, mineralizable soil C measured by Alkali also had a negative relationship with Olsen-P and positive relationship with SLAN, SOC, and $\mathrm{pH}$. Solvita had a significant relationship with CFMBC and IRGA.

SLAN had a significant positive relationship with CFMBC (0.52), Alkali (0.37), POXC (0.70), SOC (0.68), $\mathrm{pH}(0.44)$ and SOM (0.69). Quadratic fit between POXC and SLAN is presented in Figure $1(\mathrm{~d})\left(\mathrm{r}^{2}=0.59, \mathrm{p}<0.001\right)$.

Our results suggest that $\mathrm{CFMBC}$ had a close relationship with the most soil biochemical health tests. Several authors [20] [5] reported a close relationship between CFMBC and POXC. Besides, SLAN and POXC also showed a close relationship with SOM, pH, SOC and $\mathrm{NO}_{3}-\mathrm{N}$. [24] found a correlation of 0.94 between organic $\mathrm{C}$ and POXC for agricultural soils. [25] also found a positive correlation among $\mathrm{CFMBC}$, acid hydrolyzable $\mathrm{C}$, the amount of $\mathrm{C}$ respired after 12-d incubation and light fraction C. [26] also reported a strong relationship between POXC and net $\mathrm{N}$ mineralization.

Measurements of soil $\mathrm{CO}_{2}$ by IRGA and Solvita showed a strong correlation of $r=0.86$, but both did not show any relationship with Alkali. This finding was in contrast with the previous findings of strong correlations of these three methods

Table 3. Pearson correlation coefficient (r) representing relationship among soil properties and soil biological health indicators of soils collected from nine agricultural fields across the RRV $(n=45)$ (NS indicates not significant at $\mathrm{p}<0.05$ and ${ }^{\star}$ indicates the $\mathrm{p}$ value).

\begin{tabular}{|c|c|c|c|c|c|c|c|c|c|c|c|}
\hline & CFMBC & IRGA & Alkali & Solvita & SLAN & POXC & SOC & $\mathrm{pH}$ & EC & $\mathrm{NO}_{3}-\mathrm{N}$ & Olsen-P \\
\hline IRGA & NS & & & & & & & & & & \\
\hline Alkali & $0.37\left(0.01^{\star}\right)$ & NS & & & & & & & & & \\
\hline Solvita & $0.57(<0.01)$ & $0.86(<0.001)$ & NS & & & & & & & & \\
\hline SLAN & $0.52(0.001)$ & NS & $0.38(0.01)$ & NS & & & & & & & \\
\hline POXC & $0.68(<0.001)$ & NS & NS & NS & $0.70(<0.001)$ & & & & & & \\
\hline soc & $0.47(0.001)$ & NS & $0.71(<0.001)$ & NS & $0.68(<0.001)$ & $0.49(0.001)$ & & & & & \\
\hline $\mathrm{pH}$ & $0.41(0.005)$ & NS & $0.73(<0.001)$ & NS & $0.44(0.002)$ & $0.46(0.002)$ & $0.76(<0.001)$ & & & & \\
\hline EC & NS & NS & NS & NS & NS & $0.65(<0.001)$ & NS & $0.33(0.02)$ & & & \\
\hline $\mathrm{NO}_{3}-\mathrm{N}$ & $0.52(0.001)$ & NS & NS & NS & $0.72(<0.001)$ & $0.56(<0.001)$ & $0.49(0.001)$ & NS & NS & & \\
\hline Olsen-P & NS & $-0.41(0.005)$ & $-0.67(<0.001)$ & NS & NS & NS & $-0.39(0.008)$ & $-0.47(0.001)$ & $0.38(0.01)$ & NS & \\
\hline SOM & $0.74(<0.001)$ & NS & NS & NS & $0.59(<0.001)$ & $0.59(<0.001)$ & $0.57(<0.001)$ & NS & NS & $\begin{array}{c}0.62 \\
(<0.001)\end{array}$ & $\begin{array}{c}0.33 \\
(0.02)\end{array}$ \\
\hline
\end{tabular}

IRGA: Infrared Gas analysis soil respiration; SLAN: Solvita Labile Amino-Nitrogen; POXC: Permanganate-oxidizable Carbon; SOC: Soil organic Carbon; CFMBC: Chloroform fumigation extraction-microbial biomass carbon; Alkali: Base-trap method. Solvita: $\mathrm{CO}_{2}$ burst test. 

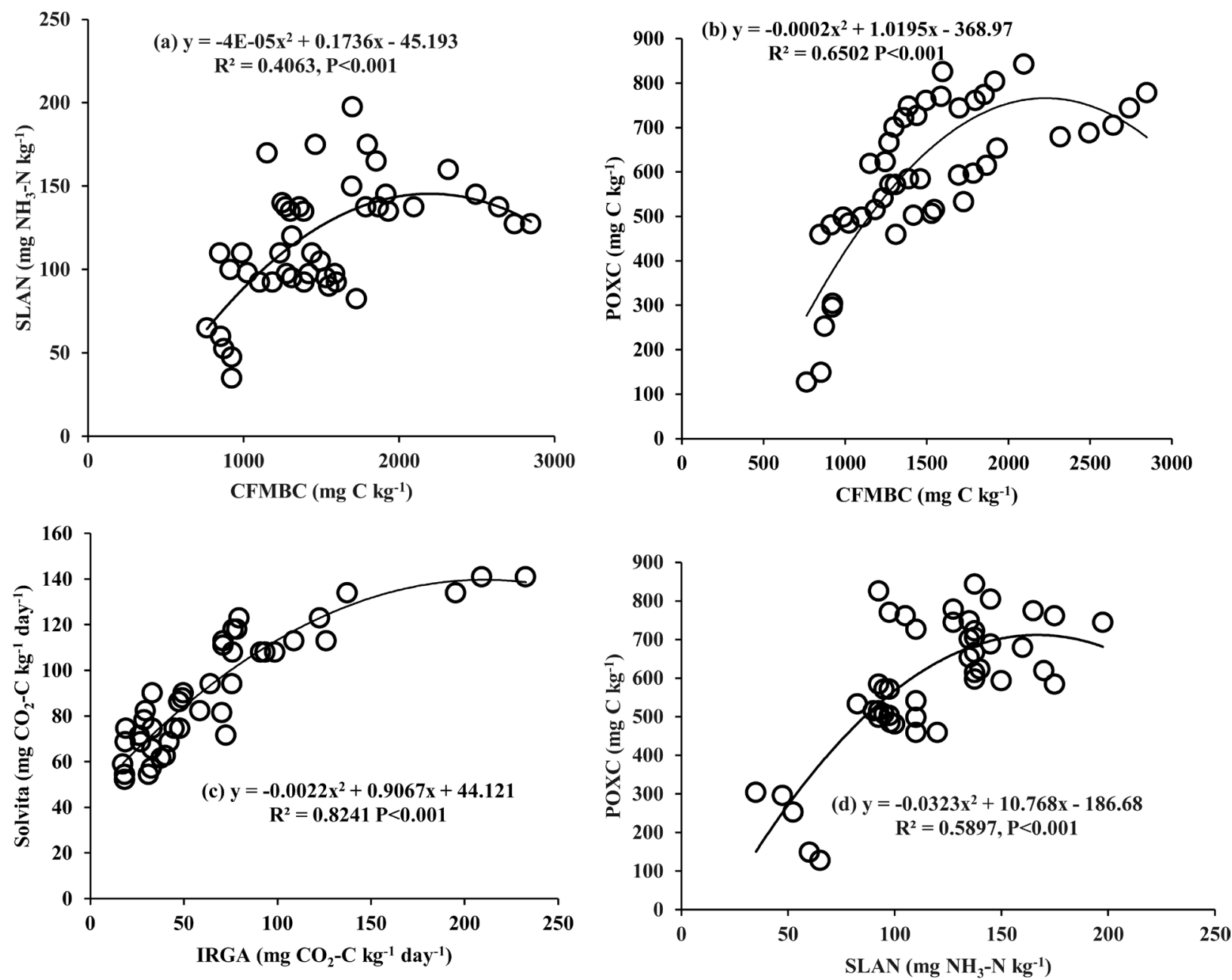

Figure 1. Quadratic fit between different soil biochemical health tests of soils collected across nine agricultural fields of the Red River Valley of North Dakota and Minnesota, (a) Solvita Labile Amino-nitrogen ( $\mathrm{mg} \mathrm{NH}_{3}-\mathrm{N} \mathrm{kg}^{-1}$ ) and CFMBC (mg C $\left.\mathrm{kg}^{-1}\right)$, (ii) POXC (mg C kg-1) and CFMBC $\left(\mathrm{mg} \mathrm{C} \mathrm{kg}{ }^{-1}\right)$, (iii) Solvita- $\mathrm{CO}_{2}$ burst test $\left(\mathrm{mg} \mathrm{CO}_{2}-\mathrm{C} \mathrm{kg}^{-1} \mathrm{day}^{-1}\right)$ and $\mathrm{CO}_{2}$ flux measured using IRGA (mg CO $\left.{ }_{2}-\mathrm{C} \mathrm{kg}^{-1} \mathrm{day}^{-1}\right)$, and (iv) POXC (mg C kg$\left.{ }^{-1}\right)$ and SLAN $\left(\mathrm{mg} \mathrm{NH}_{3}-\mathrm{N} \mathrm{kg}^{-1}\right), \mathrm{n}=45$.

[3] [27]. We hypothesized that the variations among these three methods were strongly dependent on the incubation period, the volume of the vessel and wetting methods (gravimetric vs. capillary) [26] [28]. [29] reported that the limit of quantification (lowest level that an analytical result becomes meaningful) of IRGA was significantly lower than Alkali method after day 10 of incubation. They also mentioned that CV of Alkali method was nearly $50 \%$ as compared to IRGA on day 1 .

Analysis of soil chemical properties $\mathrm{pH}$, and EC were related to rapid soil biochemical tests, SLAN and POXC. [30] concluded that microbial biomass and microbial activity tended to stabilize at $\mathrm{pH}$ values between about 5 and 7 because the differences in organic acid, total $\mathrm{N}$, and aluminum concentrations within this $\mathrm{pH}$ range are small. Finally, soil biochemical tests did not show any relationship with Olsen-P; rather extractable aluminum and iron are commonly best predictors [31]. 


\section{Conclusion}

Soil biochemical tests showed different levels of relationship with each other; no single method was found to comprehensively represent the complete soil biochemical health. Our findings emphasized that regular soil tests including, soil $\mathrm{pH}, \mathrm{EC}, \mathrm{NO}_{3}-\mathrm{N}$, and Olsen-P are also important, as they related significantly to some tests.

\section{Conflicts of Interest}

The authors declare no conflicts of interest regarding the publication of this paper.

\section{References}

[1] Doran, J.W. and Zeiss, M.R. (2000) Soil Health and Sustainability: Managing the Biotic Component of Soil Quality. Applied Soil Ecology, 15, 3-11.

[2] Morrow, J.G., Huggins, D.R., Carpenter-Boggs, L.A. and Reganold, J.P. (2016) Evaluating Measures to Assess Soil Health in Long-Term Agroecosystem Trials. Soil Science Society of America Journal, 80, 450-462.

https://doi.org/10.2136/sssaj2015.08.0308

[3] Haney, R., Brinton, W. and Evans, E. (2008) Soil $\mathrm{CO}_{2}$ Respiration: Comparison of Chemical Titration, $\mathrm{CO}_{2}$ IRGA Analysis and the Solvita Gel System. Renewable Agriculture and Food Systems, 23, 171-176. https://doi.org/10.1017/S174217050800224X

[4] Weil, R.R., Islam, K.R., Stine, M.A., Gruver, J.B. and Samson-Liebig, S.E. (2003) Estimating Active Carbon for Soil Quality Assessment: A Simplified Method for Laboratory and Field Use. American Journal of Alternative Agriculture, 18, 3-17. https://doi.org/10.1079/AJAA2003003

[5] Hurisso, T.T., Culman, S.W., Horwath, W.R., Wade, J., Cass, D., Beniston, J.W., Bowles, T.M., Grandy, A.S., Franzluebbers, A.J., Schipanski, M.E., Lucas, S.T. and Ugarte, C.M. (2016) Comparison of Permanganate-Oxidizable Carbon and Mineralizable Carbon for Assessment of Organic Matter Stabilization and Mineralization. Soil Science Society of America Journal, 80, 1352-1364. https://doi.org/10.2136/sssaj2016.04.0106

[6] Dick, W.A. and Culman, S.W. (2016) Biological and Biochemical Tests for Assessing Soil Fertility. In: Chatterjee, A. and Clay, D., Eds., Soil Fertility Management in Agroecosystems, American Society of Agronomy, Crop Science Society of America, Soil Science Society of America, Inc., Madison, WI, 134-147.

[7] Tirol-Padre, A. and Ladha, J.K. (2004) Assessing the Reliability of Permanganate-Oxidizable Carbon as an Index of Soil Labile Carbon. Soil Science Society of America Journal, 68, 969-978. https://doi.org/10.2136/sssaj2004.9690

[8] Hammac, W.A., Stott, D.E., Karlen, D.L. and Cambardella, C.A. (2016) Crop, Tillage, and Landscape Effects on Near-Surface Soil Quality Indices in Indiana. Soil Science Society of America Journal, 80, 1638-1652.

https://doi.org/10.2136/sssaj2016.09.0282

[9] Vinhal-Freitas, I.C., Corrêa, G.F., Wendling, B., Bobul'ská, L. and Ferreira, A.S. (2017) Soil Textural Class Plays a Major Role in Evaluating the Effects of Land Use on Soil Quality Indicators. Ecological Indicators, 74, 182-190.

https://doi.org/10.1016/j.ecolind.2016.11.020 
[10] Castro Lopes, A., Gomes de Sousa, D.M., Chaer, G.M., Bueno dos Reis Junior, F., Goedert, W.J. and de Carvalho Mendes, I. (2013) Interpretation of Microbial Soil Indicators as a Function of Crop Yield and Organic Carbon. Soil Science Society of America Journal, 77, 461-472. https://doi.org/10.2136/sssaj2012.0191

[11] Awale, R., Chatterjee, A. and Franzen, D. (2013) Tillage and N-Fertilizer Influences on Selected Organic Carbon Fractions in a North Dakota Silty Clay Soil. Soil and Tillage Research, 134, 213-222. https://doi.org/10.1016/j.still.2013.08.006

[12] Chatterjee, A., Cooper, K., Klaustermeier, A., Awale, R. and Cihacek, L.J. (2016) Does Crop Species Diversity Influence Soil Carbon and Nitrogen Pools? Agronomy Journal, 108, 427-432. https://doi.org/10.2134/agronj2015.0316

[13] Station, M.A.E. (1998) Recommended Chemical Soil Test Procedures for the North Central Region. North Central Regional Research Publication No. 221. http://msue.anr.msu.edu/uploads/234/68557/rec_chem_soil_test_proce55c.pdf

[14] Klute, A. (1986) Water Retention: Laboratory Methods. In: Klute, A., Ed., Methods of Soil Analysis, Part 1. Physical and Mineralogical Methods, American Society of Agronomy, Soil Science Society of America, Madison, 635-662.

https://doi.org/10.2136/sssabookser5.1.2ed.c26

[15] Jackson, M.L. (1967) Soil Chemical Analysis. Prentice-Hall of India Pvt. Ltd., New Delhi, 498.

[16] Maynard, D.G., Kalra, Y.P. and Crumbaugh, J.A. (2008) Nitrate and Echangeable Ammonium Nitrogen. In: Soil Sampling and Methods of Analysis, 2nd Edition, CRC Press, Boca Raton, 71-88.

[17] Olsen, S.R. (1954) Estimation of Available Phosphorus in Soils by Extraction with Sodium Bicarbonate. United States Department of Agriculture, Washington DC, USDA Circular 939, 1-19.

[18] Cihacek, L. and Jacobson, K. (2007) Effects of Soil Sample Grinding Intensity on Carbon Determination by High-Temperature Combustion. Communications in Soil Science and Plant Analysis, 38, 1733-1739. https://doi.org/10.1080/00103620701435506

[19] Vance, E.D., Brookes, P.C. and Jenkinson, D.S. (1987) An Extraction Method for Measuring Soil Microbial Biomass C. Soil Biology and Biochemistry, 19, 703-707. https://doi.org/10.1016/0038-0717(87)90052-6

[20] Culman, S.W., Snapp, S.S., Freeman, M.A., Schipanski, M.E., Beniston, J., Lal, R., Drinkwater, L.E., Franzluebbers, A.J., Glover, J.D., Grandy, A.S., Lee, J., Six, J., Maul, J.E., Mirksy, S.B., Spargo, J.T. and Wander, M.M. (2012) Permanganate Oxidizable Carbon Reflects a Processed Soil Fraction That Is Sensitive to Management. Soil Science Society of America Journal, 76, 494-504. https://doi.org/10.2136/sssaj2011.0286

[21] Anderson, J.P.E. (1982) Soil Respiration. In: Methods of Soil Analysis Part 2, 2nd Edition, Agronomy Monograph, ASA and SSSA, Madison, 831-871.

[22] Franzen, D.W., Nanna, T. and Norvell, W.A. (2006) A Survey of Soil Attributes in North Dakota by Landscape Position. Agronomy Journal, 98, 1015-1022. https://doi.org/10.2134/agronj2005.0283

[23] International Plant Nutrition Institute (IPNI) (2015) Soil Test Levels in North America. http://nap.ipni.net/article/NAP-3018

[24] Lucas, S.T. and Weil, R.R. (2012) Can a Labile Carbon Test Be Used to Predict Crop Responses to Improve Soil Organic Matter Management? Agronomy Journal, 104, 1160-1170. https://doi.org/10.2134/agronj2011.0415 
[25] McLauchlan, K.K. and Hobbie, S.E. (2004) Comparison of Labile Soil Organic Matter Fractionation Techniques. Soil Science Society of America Journal, 68, 1616-1625. https://doi.org/10.2136/sssaj2004.1616

[26] Wade, J., Horwath, W.R. and Burger, M.B. (2016) Integrating Soil Biological and Chemical Indices to Predict Net Nitrogen Mineralization across California Agricultural Systems. Soil Science Society of America Journal, 80, 1675-1687.

https://doi.org/10.2136/sssaj2016.07.0228

[27] Sherrod, L.A., Reeder, J.D., Hunter, W. and Ahuja, L.R. (2012) Rapid and Cost-Effective Method for Soil Carbon Mineralization in Static Laboratory Incubations. Communications in Soil Science and Plant Analysis, 43, 958-972. https://doi.org/10.1080/00103624.2012.653031

[28] Haney, R.L. and Haney, E.B. (2010) Simple and Rapid Laboratory Method for Rewetting Dry Soil for Incubations. Communications in Soil Science and Plant Analysis, 41, 1493-1501. https://doi.org/10.1080/00103624.2010.482171

[29] Franzluebbers, A.J., Hons, F.M. and Zuberer, D.A. (1995) Soil Organic Carbon, Microbial Biomass, and Mineralizable Carbon and Nitrogen in Sorghum. Soil Science Society of America Journal, 59, 460. https://doi.org/10.2136/sssaj1995.03615995005900020027x

[30] Aciego Pietri, J.C. and Brookes, P.C. (2008) Relationships between Soil pH and Microbial Properties in a UK Arable Soil. Soil Biology and Biochemistry, 40, 1856-1861. https://doi.org/10.1016/j.soilbio.2008.03.020

[31] Minasny, B. and Hatermink, A.E. (2011) Predicting Soil Properties in the Tropics. Earth-Science Reviews, 106, 52-62. https://doi.org/10.1016/j.earscirev.2011.01.005 